\title{
Effect of substitution of sugars by date powders variety H'lowa on the quality of the soft drinks
}

\begin{abstract}
This study was carried out to determine the possibility of replacement of sucrose by date powders obtained from common Algerian varieties known as low values during the manufacture of the soft drinks. In order to obtain the date powders, four varieties of dates H'amira, H'loua, Tefezouine and Timjouhart were dried at $90^{\circ} \mathrm{C}$ during $2 \mathrm{~h}$. Date powders variety H'lowa was selected according to these good qualities for substitution sucrose (yield, optical density, moisture, ash, total and reducing sugars, report Sugars/Water, proteins, the rehydration power and sensitivity in temperature). The date powder variety $H^{\prime}$ 'lowa had significantly higher color, taste and texture score followed by Tefezouine, then Timjouhart and H'mira. The total or partial replacement of sucrose by date powders variety H'lowa improves the nutritional quality of the products (acidity, reducing sugars and ash). The microbiological quality of most of the soft drinks prepared with date powders were not satisfactory as total plat count and, yeasts and moulds. Complete replacement of sucrose improves the sensory quality of soft drinks included color, taste, acidity and odor.
\end{abstract}

Keywords: date powders, h'lowa, quality, soft drinks, sucrose, replacement
Volume 3 Issue 6 - 2017

\author{
Hariri A,' Ouis $N{ }^{2}$ Bouhadi $D^{\prime}$ \\ 'Department of Microbiology Engineering and Health Safety, \\ University of Mascara, Algeria \\ ${ }^{2}$ Laboratory of Physical Chemistry of Macromolecules and \\ Biological Interfaces, University of Mascara, Algeria
}

\begin{abstract}
Correspondence: Hariri Ahmed, Bioconversion Laboratory, Microbiology Engineering and Health Safety, Faculty of Science the Nature and Life, University of Mascara (UN 290I), BP.763, Sidi Said, Mascara, 29000, Algeria, Tel 0021366172 II 90, Email haririahmed@yahoo.fr
\end{abstract}

Received: February 18, 2017| Published: September 07, 2017
Abbreviations: TPC, total plate count; TEGA, triptone extrat glucose agar; VRBL, violet red bile lactose agar; SFB, selenite-f broth; PDA, potato dextrose agar

\section{Introduction}

The date palm Phoenix dactylifera $L$. belonging to the Arecaceae family represents an important economical and ecological culture for many countries. ${ }^{1}$ It is a delicious, monocot plant that has been cultivated across the Middle East and North Africa for over 5000 years. ${ }^{2}$ Date palm cultivars are divided to three main types according to their fruit moisture content as soft, semi-dry and dry cultivars. ${ }^{3}$ Dates contain a high percentage of sugars reaching $88 \%$ in some varieties ${ }^{4}$ and mineral salts ${ }^{5}$ but low in fat and virtually free from cholesterol and sodium. There is an important genetic biodiversity of the date palm in the Maghreb region (Algeria, Tunisia and Morocco) with more than 1000 varieties. ${ }^{6}$ Algeria is a date producer country with an annual production of more than 500,000t. The most significant part of this quantity constitutes common dates (all other varieties from DegletNour). The production of common dates in Algeria reached 244577t. ${ }^{7}$ The dates destined to the local consumption and to the export has morphological, microbiological and physicochemical characteristics well-defined. Common dates are known as low value varieties ${ }^{8}$ which cannot be directly supplied in the market due to hygienic and economic problems. Utilization of such surplus by date processing companies into more value added derivatives and also by being used for production of new food products is very important in increasing the income of the sector.

Soft drinks are enormously popular beverages consisting primarily of carbonated water, sugar and flavorings that are usually served cold. ${ }^{9}$ Unpasteurized soft drinks are preferred by the consumers because of the "fresh flavor" attributes and low cost. ${ }^{10}$ The high consumption rate of soft drink is attributed to the characteristic taste and flavor as well as their thirst quenching potential. ${ }^{11}$ These characteristics are defined by the constituents present such as sugar which is responsible for its sweetness, carbonated water which is water compressed with carbon dioxide to make it an ultimate thirst quencher and flavoring agents to add flavor to the drinks. In addition to taste satisfaction, soft drinks contain other constituents such as vitamins, phosphates, acids, antioxidants, etc. which are of nutritional and health benefits to the body. ${ }^{12}$ Date palm is very rich in sugars and sweetness; it can be used for substitution of these components for manufacture of soft drinks. The objective of this work is to characterize and study the effect of total or partial replacement of sucrose by date powders variety $H^{\prime}$ lowa in the quality of soft drink.

\section{Material and methods}

\section{Vegetable material and preparation of date pow- ders}

The dates used in current experiments were varieties half soft, known as H'amira, H'loua, Tefezouine and Timjouhart badly exploited, cultivated in the area of Adrar (South of Algeria) and harvested in the month of October 2014. For the preparation of the date powders, theses fruits have been washed in order to eliminate sand and dust, and then cut into the small particles (1-3cm). Dates are dried at $80-90^{\circ} \mathrm{C}$ and the drying process was continued until the pulp moisture content did not decrease significantly with increasing drying time and/or the colour change is not visible to the naked eye (Figure 1). The moisture content thus obtained was considered as equilibrium moisture content. ${ }^{13,14}$

\section{Biochemical analysis}

Samples were analyzed chemically according to the official methods of analysis described by the Association of Official Analytical Chemist. ${ }^{15}$ Yield of date powder (or date flesh) in \% is the ratio of the mass of powder (or date flesh) obtained/mass of fruit entire. For determination of the optical density, $50 \mathrm{~mL}$ of diluted sample was 
centrifuged at $2300 \mathrm{rpm}$ for 20 minutes. $25 \mathrm{~mL}$ of the supernatant was mixed with $25 \mathrm{~mL}$ of $95 \%$ ethanol and then filtered. The optical density is measured by a spectrophotometer at $420 \mathrm{~nm} .{ }^{16} \mathrm{The} \mathrm{pH}$ was measured by using a digital $\mathrm{pH}$ meter and titratable acidity was determined by manual titration of suitable quantity $(10 \mathrm{~g})$ with standardized $0.1 \mathrm{~N}$ $\mathrm{NaOH}$ using phenolphthalein as indicator. The volume of $\mathrm{NaOH}$ required to neutralize the date was recorded and used to calculate the content of titratable acids. The moisture content was determined by measuring the mass of the sample before and after water is removed by evaporation at $105^{\circ} \mathrm{C}$ for $24 \mathrm{~h}$ (until constant mass was achieved) Total nitrogen of date and proteins content were determined by the method of Kjeldahl digestion and distillation apparatus. ${ }^{15}$ Total and reducing sugars were determined colorimetrically at $480 \mathrm{~nm}$ by Dubois method. ${ }^{17}$ Standards were prepared with glucose solutions at different concentrations. The ash content was determined according to the AOAC official method by incineration five gram of date at a temperature of $600^{\circ} \mathrm{C}$ during $3 \mathrm{~h} .{ }^{15}$

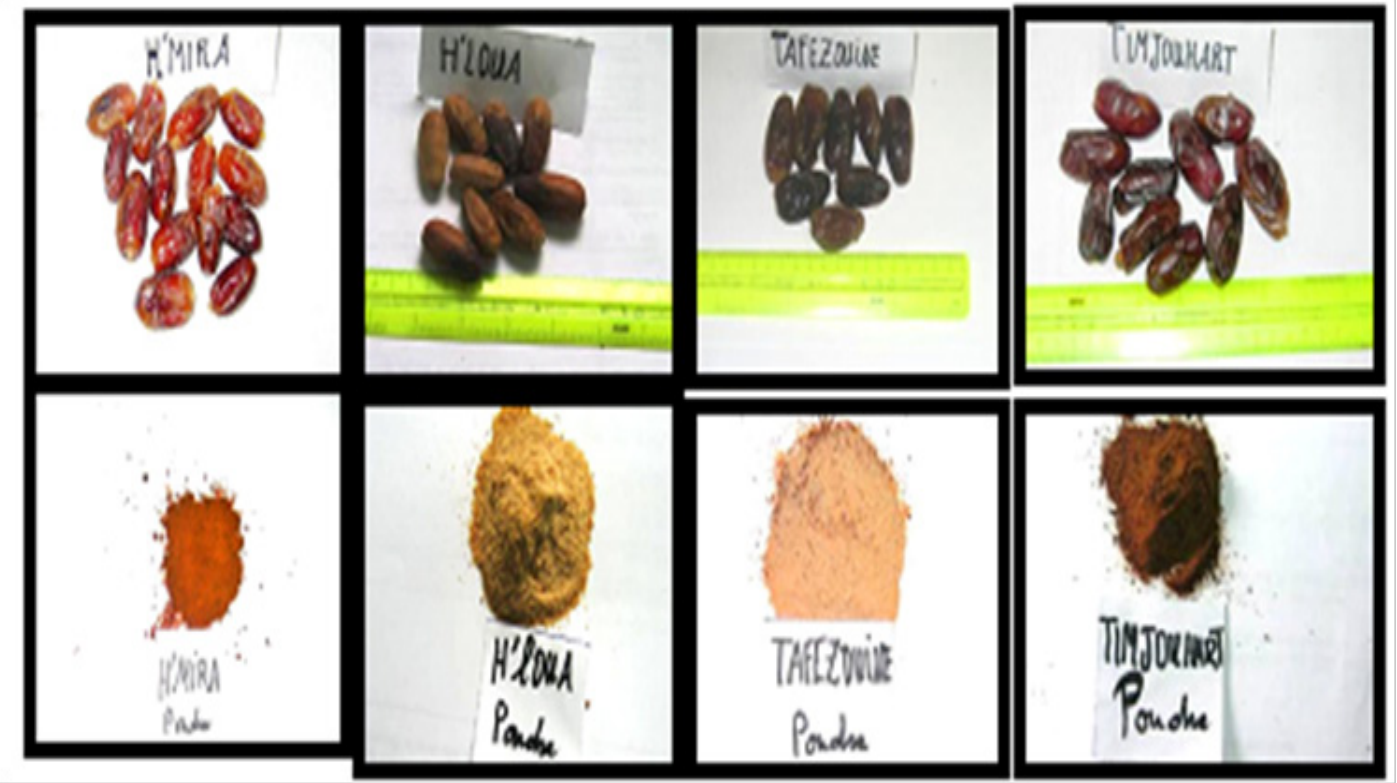

Figure I All varieties of dates: H'amira, H'loua, Tefezouine and Timjouhart (fruit entire and powders).

\section{Microbiological analysis}

The microbiological quality was determined by enumeration of total plate count (TPC) in the TGEA (Triptone Extract Glucose Agar) after incubation for $72 \mathrm{~h}$ at $30^{\circ} \mathrm{C}$. All colonies were counted on those plates containing 30-300 colonies and multiplied by dilution factor. Arithmetic average was counted as total plate count per gram. ${ }^{18}$ Faecal streptococci were counted in Roche presumptive medium contains sodium azohydrate and Litsky confirmation medium contains sodium azohydrate and purple ethyl. Search sulfite-reducing Clostridium can be done by counting the sporulated forms which develop in media VF containing sodium sulphite and iron alum after $48 \mathrm{~h}$ at $37^{\circ} \mathrm{C} .{ }^{19}$ The total and fecal coliforms were counted, respectively desoxycholate lactose agar and violet red bile lactose agar (VRBL) after 24 to $48 \mathrm{~h}$ at 37 for total coliforms and at and $44^{\circ} \mathrm{C}$ for faecal coliforms, Staphylococcus aureus on Giolitti Cantonii and Chapman agar after 24 to $48 \mathrm{~h}$ at $37^{\circ} \mathrm{C}$, mean Salmonella in Salmonella agar and incubated for 24 to $48 \mathrm{~h}$ at $37^{\circ} \mathrm{C}$, after enrichment in Selenite-F Broth (SFB) medium for 24 to $48 \mathrm{~h}$ at $37^{\circ} \mathrm{C}$. The yeasts and moulds on potato dextrose agar (PDA) supplemented with oxy-tetracycline after 5 days at $25^{\circ} \mathrm{C} .{ }^{20} \mathrm{All}$ colonies were counted on the plates containing less than 50 colonies and multiplied by dilution factor. Arithmetic average was counted as total plate count per gram.

\section{Rheological analysis of the date powder}

The date powder is known by its wealth of sugars and its low content of proteins. The aptitude of the date to undergo a complementary thermal drying for obtaining powders was already underlined. ${ }^{14,21}$
Then, the comprehension of the behavior of the powder is imperative to lead a final product with best physical quality. A dehydrated product adsorbs a large amount of water compared to a fresh product. $10 \mathrm{~g}$ of different powders are exposed to air for 2 hours, then weighed again the product. The power of hydration in $\%$ is calculated by the following formula: [the mass of the test after exposure to fresh air in (g)-the mass of the sample before exposure to air in (g)/the mass of the sample before exposure to air in $(\mathrm{g})]^{*} 100$. The temperature has an effect on the stability of dehydrated products and manifested by the agglomeration, browning and blackening. Dates powders are exposed to different temperatures and check their quality.

\section{Sensory evaluation ${ }^{22}$}

All the samples were evaluated for sensory characteristics (taste, color, odor, acidity and texture) by 14 panelists (students and technicians from University of Mascara, Algeria); using a point scale (7: good, 5: acceptable, 3: poor, 1: bad).

\section{Preparation of Soft Drinks}

In view of the rheological, biochemical and microbiological properties of date powders, the highest color, taste and texture scores, it is possible to use the date powders variety ( $H^{\prime}$ lowa) in many food preparations. A soft drink control was prepared by dissolving $125 \mathrm{~g}$ of sucrose, $0.75 \mathrm{~g}$ of citric acid and $1.5 \mathrm{ml}$ of aroma in $250 \mathrm{~mL}$ water. Samples were prepared by total replacing of sugars by $125 \mathrm{~g}$ of date powders (A), partial substitution of sugars: $62.5 \mathrm{~g}$ sucrose, $62.5 \mathrm{~g}$ date powders (B) and partial substitution of sugars: $62.5 \mathrm{~g}$ sucrose, $62.5 \mathrm{~g}$ date powders without aroma (C). All samples underwent the 
following stages of manufacture: bottle washing, adding ingredients, filtration for tests $\mathrm{A}, \mathrm{B}$ and $\mathrm{C}$, injecting carbonated water, capping and storage at $4^{\circ} \mathrm{C}$.

\section{Results and discussion}

\section{Biochemical analysis of date flesh and date powders}

According to the results clearly presented in Table 1 , there is a difference between the yield of each flesh cultivar and powders. The variety Tafezouine has the best yield $(93.32 \pm 0.4)$ followed by H'mira (88.70 \pm 0.2$)$, then Timjouhart $(86.30 \pm 0.3)$ and H'loua $(71.22 \pm 0.1)$. For the yield of date powders, the ranking is as following the H'loua, H'mira, Timjouhart and Tafezouine. The variation in yield between the dates flesh and powders is due to their difference in water content. Optical density is a parameter that judges the polymerization reactions and browning that generated products may give a darker color to the product and evaluates the nutritional quality. The colour is an important quality attribute of date flesh and powders. It is essential for food processor to minimize the colour losses during processing and storage. ${ }^{23}$ The lowest optical density is obtained with the variety $H^{\prime} l o u a$ because it has low water content and thus a low drying time compared to H'mira. The $\mathrm{pH}$ of the flesh dates range from 5.61 \pm 0.01 to $5.90 \pm 0.02$, the results obtained concord with those of Belguedj ${ }^{24}$ and Abekhti et al. ${ }^{25}$ For determination of titrable acidity, our results concord with results obtained by Belguedj ${ }^{24}$ except for that of $H^{\prime}$ mira that shows higher values may be due to the microbiological activity just before drying, because the acidity of providing order of $3.2 \mathrm{~g} / \mathrm{kg}$, but according to our results, there is an acidity of about $4.16 \pm 0.2 \mathrm{~g}$ / $\mathrm{kg}$. In this study, the moisture varies from one variety to another, generally dry and semi soft varieties have lower water content compared to soft varieties. Ranked down as moisture respectively Tafezouine, H'mira, Timjouhart, H'loua. After drying, the driest date powder is one of the varieties H'loua. The high moisture content facilitates spoilage of dates and low moisture content will lead to dry dates not acceptable to consumers. Ours results are agreement from the observation of Barreveld ${ }^{26}$ who reported that moisture content in date fruits at different stages of development were about $50-60 \%$ for sweet khalal, fleshes varied between 9.73 and $17.52 \mathrm{~g} / 100 \mathrm{~g}$, being lowest in Um-sellah and highest in Shahal. Toutain ${ }^{27}$ considered dates as soft, if they present water content more than $30 \%$, dry if this rate is less than $10 \%$ and halfsoft if the rate is between 10 and $30 \%$. This nomenclature permits us to classify theses varieties of date as halfsoft. The moisture content of date flesh of various varieties is not agreement with results $(64.34 \%)$ obtained by Omowunmi et al. ${ }^{28}$ and agreement with results $(10.57 \%)$ obtained by Abekhti et al. ${ }^{25}$ The moisture content of date powders obtained by El-Sharnouby et al. ${ }^{29}$ was $11.0 \%$ and the moisture of date flesh obtained by Salim-ur-Rehman et al. ${ }^{30}$ is $17.7 \%$. Dates are a good source of certain minerals (potassium and calcium), this explains considerable ash content in dates. The ash content obtained in this work was for all varieties vary $1.82 \pm 0.02$ to $2.05 \pm 0.03$ for flesh date and $2.13 \pm 0.02$ to $2.57 \pm 0.03$ for date powders. Ash in dates powders are higher than those given by flesh dates because the water evaporation. The difference between flesh date and powder date is $0.3 \%$ for H'mira, H'loua and $0.5 \%$ for Timjouhart and Tafezouine. This variation is due to the deference between the water contents of these varieties. Ash content of date powder obtained by El-Sharnouby et al. ${ }^{29}$ was $2.6 \%$. For determination of reducing and total sugars, the results of flesh fruits (edible part) are similar to those given by Belguidj. ${ }^{24}$ The carbohydrate content of date flesh of various varieties is agreement with results $(65 \%)$ obtained by Omowunmi et al. ${ }^{28}$ Amoros et al. ${ }^{31}$ found that the total sugar concentration in Caqui 24 and Caqui 22 date fruits ranged from 424 to $542 \mathrm{~g} \mathrm{~kg} 1$. Mikki ${ }^{32}$ reported that Saudi date varieties contain about $70 \%$ reducing sugars with an almost equal quantity of glucose and fructose. In date powders, the values of total and reducing sugars are very high for Timjouhart, H'loua and H'mira and slightly higher for Tafezouine. The total sugar content give the ranking; H'loua, Timjouhart H'mira and Tafezouine. The reducing sugars content for all varieties date powders obtained is not agreement with results $\left(50 \mathrm{~g} . \mathrm{L}^{-1}\right)$ obtained by Shahravy et al..$^{33}$ and results $(60 \pm 0,4 \%)$ for date powders observed by Benahmed et al. ${ }^{13}$ The report Sugars/Water gives an idea of the osmotic pressure, the absorption capacity of power, energetic and nutritional value and the water activity (Aw) which influences the bacteria charge. The classification of powders report is as follows: H'loua, Timjouhart, H'mira and Tafezouine. According to Maatallah, ${ }^{34}$ protein levels are of the order of $2 \%$, but according to our results, these quantities vary between $0.01 \pm 0.02 \%$ and $0.77 \pm 0.03 \%$. Protein content of date powder obtained by El-Sharnouby et al. ${ }^{29}$ was $2.1 \%$. Borchani et al. ${ }^{35}$ analysed eleven Tunisian cultivars of date for protein and found the highest protein content of $2.85 \mathrm{~g} / 100 \mathrm{~g}$ dry matter. The crude protein of date flesh obtained by Salim-ur-Rehman et al. ${ }^{30}$ is $3.5 \%$.

Table I Biochemical and microbiological analysis of date flesh (DF) and date powder (DP)

\begin{tabular}{lllll}
\hline Date powders/parameters & Timjouhart & Tafezouine & H'loua & H'mira \\
\hline \multirow{2}{*}{ Yield \% } & DF. $86.30 \pm 0.3$ & DF. $93.32 \pm 0.4$ & DF. $71.22 \pm 0.1$ & DF. $88.70 \pm 0.2$ \\
& DP. $44.15 \pm 0.2$ & DP. $40.74 \pm 0.2$ & DP. $56.01 \pm 0.3$ & DP. $47.78 \pm 0.3$ \\
O D at $420 \mathrm{~nm}$ & DF. $0.47 \pm 0.01$ & DF. $0.50 \pm 0.02$ & DF. $0.31 \pm 0.01$ & DF. $0.49 \pm 0.02$ \\
& DP. $1.35 \pm 0.01$ & DP. $1.33 \pm 0.01$ & DP. $0.66 \pm 0.02$ & DP. $1.41 \pm 0.02$ \\
$\mathrm{pH}$ & DF. $5.73 \pm 0.03$ & DF. $5.65 \pm 0.04$ & DF. $5.90 \pm 0.02$ & DF. $5.61 \pm 0.01$ \\
& DP. $5.03 \pm 0.03$ & DP. $5.29 \pm 0.03$ & DP. $5.49 \pm 0.03$ & DP. $5.31 \pm 0.01$ \\
Acidity titrable g/Kg & DF. $3.6 \pm 0.2$ & DF. $3.7 \pm 0.3$ & DF. $2.38 \pm 0.1$ & DF. $2.52 \pm 0.1$ \\
& DP. $3.5 \pm 0.1$ & DP. $2.04 \pm 0.3$ & DP. $4.1 \pm 0.1$ & DP. $4.16 \pm 0.2$ \\
Moisture \% & DF. $16.11 \pm 0.3$ & DF. $28.31 \pm 0.4$ & DF. $13.4 \pm 0.2$ & DF. $19.70 \pm 0.2$ \\
& DP. $4.26 \pm 0.3$ & DP. $5.23 \pm 0.5$ & DP. $4.04 \pm 0.3$ & DP. $4.63 \pm 0.2$ \\
Ash \% & DF. $2.05 \pm 0.03$ & DF. $2.04 \pm 0.03$ & DF. $1.9 \pm 0.03$ & DF. $1.82 \pm 0.02$ \\
& DP. $2.57 \pm 0.03$ & DP. $2.55 \pm 0.03$ & DP. $2.23 \pm 0.03$ & DP. $2.13 \pm 0.02$ \\
\hline
\end{tabular}




\begin{tabular}{lllll} 
Table Continued.. & & & \\
\hline Date powders/parameters & Timjouhart & Tafezouine & H'loua & H'mira \\
\hline Reducing sugars \% & DF. $41.20 \pm 0.3$ & DF. $45.2 \pm 0.3$ & DF. $46.23 \pm 0.3$ & DF. $58.1 \pm 0.1$ \\
& DP. $68.7 \pm 0.2$ & DP. $47.11 \pm 0.4$ & DP. $62.8 \pm 0.1$ & DP. $77.50 \pm 0.2$ \\
Total sugars \% & DF. $62.7 \pm 0.4$ & DF. $54.4 \pm 0.3$ & DF. $84.11 \pm 0.4$ & DF. $62.1 \pm 0.2$ \\
& DP. $71.6 \pm 0.4$ & DP. $61.9 \pm 0.3$ & DP. $85.70 \pm 0.2$ & DP. $63.4 \pm 0.4$ \\
Sugars/water & DF. 3.89 & DF. 1.92 & DF. 6.27 & DF. 3.15 \\
& DP. 16.80 & DP. 11.83 & DP. 21.21 & DP. 13.69 \\
Proteins \% & DF. $0.77 \pm 0.03$ & DF. $0.53 \pm 0.04$ & DF. $0.48 \pm 0.03$ & DF. $0.65 \pm 0.02$ \\
& DP. $0.01 \pm 0.02$ & DP. $0.22 \pm 0.02$ & DP. $0.27 \pm 0.1$ & DP. $0.37 \pm 0.02$ \\
Total Plate Count UFC/g & DF. 6000 & DF. 7000 & DF. 8000 & DF. 400 \\
& DP. 0 & DP. 10 & DP. 14 & DP. 0 \\
Yeasts and moulds UFC/g & DF. 2000 & DF. 300 & DF. 3500 & DF. 300
\end{tabular}

Vales represent Mean $\pm s d ; n=3$

\section{Microbiological analysis of date flesh and date pow- ders}

According to our results (Table 1), the total plat count (TPC) is very high and this is logical because the varieties of dates are used properly packed and marketed under the same conditions that are unhygienic and that because bacterial contamination. This increase might be due to increase of moisture in date flesh. The change in TPC for various varieties is in conformity with the findings of Al-Hooti et al. ${ }^{5}$ But after drying, the number of bacteria decreases totally, absence in powder of Timjouhart and H'loua and very limited number in the other two varieties (10CFU/g for Tafezouine and 14CFU/g for H'mira). The presence of yeasts and moulds causes an alteration, modification of the nutritional value and the occurrence of undesirable flavor. ${ }^{36}$ The number of yeast and moulds is low in the date powders compared to the date flesh. Note the total absence of faecal streptococci, sulphite-reducing Clostridium, Staphylococcus aureus, coliforms and Salmonella. It can be reported the presence of tannins that limit the presence of certain bacteria in dates.

\section{Rheological analysis of the date powders}

For the rehydration power, the best range is Hloua with $4 \pm 0.2 \%$ followed by Timjouhart $100.2 \%$, Tafezouine $12 \pm 0.3$ and H'mira $15 \pm 0.4$. There is a very significant effect of temperature on the color and the state of agglomeration of the powders. The descending ranking of the sensitivity is H'mira, Timjouhart, Tafezouine and H'loua. This sensitivity can be explained by the variable content of sugar in dates which give stickiness to agglomerates by their crystal form and blackening can be attributed to the caramelization of its sugars (Figure 2).

\section{Results of sensory evaluation of date powders}

Table 2 shows the results obtained for the sensory analysis carried out of the assay. The date powder variety H'lowa had significantly higher color, taste and texture score followed by Tefezouine, then Timjouhart and H'mira. Date fruits and date powders may be considered as an almost ideal food providing a wide range of essential nutrients and potential health benefits. ${ }^{37}$

\section{Results of Biochemical analysis of soft drinks}

Several studies have been carried out to incorporate dates in production of different food products such as biscuit, ${ }^{29}$ tomato ketchup, ${ }^{38}$ chocolate toffee, ${ }^{8}$ bread, ${ }^{39}$ low caloric cakes,${ }^{40}$ and yogurt. ${ }^{41}$ This study was carried out to determine the possibility of substitution of sucrose by date powders during the manufacturing of soft drink products. $\mathrm{pH}$ values in Table 3 show that all soft drinks were low $\mathrm{pH}$ due to its ingredients like acid, with control having the lowest $\mathrm{pH}$ (4.190.1) and Sample A (total replacement of sugars by date powders) having the highest $(4.4 \pm 0.2)$. The reason behind the low $\mathrm{pH}$ values could be as a result of the presence of $\mathrm{CO}_{2}$ gas or other acids such as citric acid used as preservatives by the manufactures of these soft drinks. ${ }^{42-44}$ Our results were corroborated by Lin et al. ${ }^{45}$ who reported that all kinds of soft drinks are acidic $\mathrm{pH}$ and that cola drinks specifically make our bodies poor in oxygen. The acidity is very high in Sample A, this is due to the presence of certain organic acids in the date powder. The total solid content of control is $9.8 \pm 0.2 \%$. The use of date powders causes a slight decrease of the total solids caused by its water content $(4.04 \pm 0.3 \%)$ compared to sugar which is $0.6 \%$. The reducing sugar content of the Control sample is $9.78 \pm 0.3 \%$. According to the results, we notice that there's a relationship between the levels of reducing sugars and the quantity of the date powders added. The replacement of sugar by the date powder (Samples A, B and C) improves the nutritional quality of the product. This is due to the richness and the nature of the sugars content of the date powders $62.8 \pm 0.1 \%$. The ash content in our samples varies substantially with the amount of the date powders used. The replacement of sugar by the date powder as raw material (100\% for sample A, and 50\% for Sample $\mathrm{B}$ and C) causes an increase in ash content compared to the control. This is due to the presence of minerals salts in the dates of powders.

\section{Results of microbiological analysis}

From the study it was clear that all soft drinks contain a significant amount of microorganisms (Table 3). The average total viable count (microbial load) showed the presence of microbes in all the drinks analyzed in this study in the range of $8.8 \times 10^{4}$ for control to $12 \times 10^{4} \mathrm{cfu} /$ $\mathrm{ml}$. The study showed that sample A (total substitution of sugars by date powders) was most contaminated with a count of $12 \times 10^{4} \mathrm{cfu} / \mathrm{ml}$. Microbial load of sample B and C (partial substitution of sugars by date powders) was $9.2 \times 10^{4} \mathrm{cfu} / \mathrm{ml}$ and $9 \times 10^{4} \mathrm{cfu} / \mathrm{ml}$ respectively. The average yeasts and moulds range of $4 \times 10^{3}$ for control to $5.3 \times 10^{3} \mathrm{cfu} /$ $\mathrm{ml}$ for A, then $4 \times 10^{4} \mathrm{cfu} / \mathrm{ml}$ for B and $6.4 \times 10^{4} \mathrm{cfu} / \mathrm{ml}$ for C. Ours results are agreement with results obtained by Khan et al. ${ }^{46}$ The highest 
contamination was recorded in Sample A with total replacement of sugars by date powders. It might be due to the raw materials used in this drink (date powders). Bacterial load in control soft drink was comparatively low. It may be due to low $\mathrm{pH}$. The low $\mathrm{pH}$ greatly limits the number and the type of bacteria that can survive or grow at that $\mathrm{pH} .{ }^{47}$ From the data presented in the current study, it could be concluded that the microbiological quality of most of the drinks prepared with date powders were not satisfactory as total plat count and, yeasts and moulds. Ahmed et al ${ }^{48}$ found a range of $3 \times 10^{2}$ to $9.6 \times 10^{8}$ microorganisms in freshly squeezed fruit juices sold in Dhaka City. The presence of total coliforms in all drinks implied a negative relation with food quality and safety. The results show total absence of theses microorganism in all samples analysed. Present studies clearly indicated the absence of different types of fecal coliforms namely and Salmonella in all the drinks. The water added during preparation was likely to provide possible sources of additional bacterial contamination. ${ }^{49}$ Furthermore, these soft drinks were left in ambient temperature which may have led to the proliferation of contaminating bacteria resulting in increased bacterial counts. ${ }^{49}$ Spoilage of soft drinks is caused by a limited number of yeasts, moulds and acid tolerant bacteria. Spoilage effects include formation of clouds, particulates, taints and excessive gas.

\section{Results of sensory evaluation}

Table 4 show the results obtained for the sensory analysis carried out of the assay. Partial replacement of $62.5 \mathrm{~g}$ sugars by $62.5 \mathrm{~g}$ of the date powders (Samples B and C) improves the color, taste, acidity and odor of soft drinks.

Table 2 Sensory evaluation of date powders

\begin{tabular}{|c|c|c|c|c|c|}
\hline Sensory characteristics & Date varieties & Good & Acceptable & Poor & Bad \\
\hline \multirow{4}{*}{ Color } & Tefezouine & 50 & 36 & 14 & I \\
\hline & Timjouhart & 14 & 50 & 22 & 14 \\
\hline & H'loua & 79 & 14 & 7 & l \\
\hline & H'mira & 14 & 22 & 43 & 21 \\
\hline \multirow{4}{*}{ Taste } & Tefezouine & 43 & 36 & 21 & I \\
\hline & Timjouhart & 21 & 44 & 21 & 14 \\
\hline & H'loua & 57 & 36 & 7 & l \\
\hline & H'mira & 7 & 14 & 43 & 36 \\
\hline \multirow{4}{*}{ Texture } & Tefezouine & 57 & 29 & 14 & I \\
\hline & Timjouhart & 36 & 43 & 21 & I \\
\hline & H'loua & 71 & 21 & 8 & I \\
\hline & H'mira & 21 & 57 & 22 & l \\
\hline
\end{tabular}

Table 3 Biochemical and microbiological analysis of all soft drinks

\begin{tabular}{lllll}
\hline Parameters & Control & A & B & C \\
\hline Total Solid Content \% & $9.8 \pm 0.2$ & $8.15 \pm 0.3$ & $8.95 \pm 0.1$ & $10.4 \pm 0.2$ \\
$\mathrm{pH}$ & $4.19 \pm 0.1$ & $4.4 \pm 0.2$ & $4.33 \pm 0.2$ & $4.36 \pm 0.1$ \\
Ash \% & $0.1 \pm 0.2$ & $0.2 \pm 0.2$ & $0.16 \pm 0.1$ & $0.26 \pm 0.1$ \\
Acidity & $5 \pm 0.3$ & $35 \pm 0.4$ & $30 \pm 0.4$ & $30 \pm 0.4$ \\
Reducing sugars \% & $9.78 \pm 0.3$ & $10.98 \pm 0.2$ & $9.8 \pm 0.3$ & $9.84 \pm 0.2$ \\
Total Plat Count & $8.8 * 10^{4}$ & $12 * 10^{4}$ & $9.2 * 10^{4}$ & $9 * 10^{4}$ \\
Yeasts and moulds & $4 * 10^{3}$ & $5.3 * 10^{3}$ & $4 * 10^{4}$ & $6.4 * 10^{4}$ \\
\hline
\end{tabular}

Control: ( $250 \mathrm{ml}$ water, $125 \mathrm{~g}$ sucrose, $1.5 \mathrm{ml}$ aroma, $075 \mathrm{~g}$ citric acid, $0 \mathrm{~g}$ date powders).

A. $(250 \mathrm{ml}$ water, $0 \mathrm{~g}$ sucrose, $1.5 \mathrm{ml}$ aroma, $075 \mathrm{~g}$ citric acid, $125 \mathrm{~g}$ date powders).

B. $(250 \mathrm{ml}$ water, $62.5 \mathrm{~g}$ sucrose, $1.5 \mathrm{ml}$ aroma, $075 \mathrm{~g}$ citric acid, $62.5 \mathrm{~g}$ date powders).

C. $(250 \mathrm{ml}$ water, $62.5 \mathrm{~g}$ sucrose, $0 \mathrm{ml}$ aroma, $075 \mathrm{~g}$ citric acid, $62.5 \mathrm{~g}$ date powders). 
Table 4 Sensory evaluation of all soft drinks

\begin{tabular}{|c|c|c|c|c|c|}
\hline $\begin{array}{l}\text { Sensory } \\
\text { Characteristics }\end{array}$ & Soft Drinks & Good & Acceptable & Poor & Bad \\
\hline \multirow{4}{*}{ Color } & $\begin{array}{l}\text { Control }(250 \mathrm{ml} \text { water, } 125 \mathrm{~g} \text { sucrose, } 1.5 \mathrm{ml} \text { aroma, } 075 \mathrm{~g} \text { citric acid, } 0 \mathrm{~g} \text { date } \\
\text { powders) }\end{array}$ & 65 & 20 & 15 & I \\
\hline & $\begin{array}{l}\text { A ( } 250 \mathrm{ml} \text { water, } 0 \mathrm{~g} \text { sucrose, } 1.5 \mathrm{ml} \text { aroma, } 075 \mathrm{~g} \text { citric acid, } 125 \mathrm{~g} \text { date } \\
\text { powders) }\end{array}$ & 55 & 25 & 5 & 15 \\
\hline & $\begin{array}{l}\text { B ( } 250 \mathrm{ml} \text { water, } 62.5 \mathrm{~g} \text { sucrose, } 1.5 \mathrm{ml} \text { aroma, } 075 \mathrm{~g} \text { citric acid, } 62.5 \mathrm{~g} \text { date } \\
\text { powders) }\end{array}$ & 75 & 15 & 10 & I \\
\hline & $\begin{array}{l}\mathrm{C}(250 \mathrm{ml} \text { water, } 62.5 \mathrm{~g} \text { sucrose, } 0 \mathrm{ml} \text { aroma, } 075 \mathrm{~g} \text { citric acid, } 62.5 \mathrm{~g} \text { date } \\
\text { powders) }\end{array}$ & 70 & 15 & 15 & I \\
\hline \multirow{4}{*}{ Taste } & $\begin{array}{l}\text { Control }(250 \mathrm{ml} \text { water, } 125 \mathrm{~g} \text { sucrose, } 1.5 \mathrm{ml} \text { aroma, } 075 \mathrm{~g} \text { citric acid, } 0 \mathrm{~g} \text { date } \\
\text { powders) }\end{array}$ & 65 & 20 & 15 & I \\
\hline & $\begin{array}{l}\text { A ( } 250 \mathrm{ml} \text { water, } 0 \mathrm{~g} \text { sucrose, } 1.5 \mathrm{ml} \text { aroma, } 075 \mathrm{~g} \text { citric acid, } 125 \mathrm{~g} \text { date } \\
\text { powders) }\end{array}$ & 50 & 15 & 15 & 20 \\
\hline & $\begin{array}{l}\text { B ( } 250 \mathrm{ml} \text { water, } 62.5 \mathrm{~g} \text { sucrose, } 1.5 \mathrm{ml} \text { aroma, } 075 \mathrm{~g} \text { citric acid, } 62.5 \mathrm{~g} \text { date } \\
\text { powders) }\end{array}$ & 70 & 15 & 15 & I \\
\hline & $\begin{array}{l}\text { C ( } 250 \mathrm{ml} \text { water, } 62.5 \mathrm{~g} \text { sucrose, } 0 \mathrm{ml} \text { aroma, } 075 \mathrm{~g} \text { citric acid, } 62.5 \mathrm{~g} \text { date } \\
\text { powders) }\end{array}$ & 75 & 20 & 5 & 1 \\
\hline \multirow{4}{*}{ Acidity } & $\begin{array}{l}\text { Control }(250 \mathrm{ml} \text { water, } 125 \mathrm{~g} \text { sucrose, } 1.5 \mathrm{ml} \text { aroma, } 075 \mathrm{~g} \text { citric acid, } 0 \mathrm{~g} \text { date } \\
\text { powders) }\end{array}$ & 55 & 20 & 15 & 10 \\
\hline & $\begin{array}{l}\text { A ( } 250 \mathrm{ml} \text { water, } 0 \mathrm{~g} \text { sucrose, } 1.5 \mathrm{ml} \text { aroma, } 075 \mathrm{~g} \text { citric acid, } 125 \mathrm{~g} \text { date } \\
\text { powders) }\end{array}$ & 80 & 10 & 10 & I \\
\hline & $\begin{array}{l}\text { B ( } 250 \mathrm{ml} \text { water, } 62.5 \mathrm{~g} \text { sucrose, } 1.5 \mathrm{ml} \text { aroma, } 075 \mathrm{~g} \text { citric acid, } 62.5 \mathrm{~g} \text { date } \\
\text { powders) }\end{array}$ & 60 & 20 & 15 & 5 \\
\hline & $\begin{array}{l}\mathrm{C}(250 \mathrm{ml} \text { water, } 62.5 \mathrm{~g} \text { sucrose, } 0 \mathrm{ml} \text { aroma, } 075 \mathrm{~g} \text { citric acid, } 62.5 \mathrm{~g} \text { date } \\
\text { powders) }\end{array}$ & 75 & 15 & 10 & I \\
\hline \multirow{4}{*}{ Odor } & $\begin{array}{l}\text { Control }(250 \mathrm{ml} \text { water, } 125 \mathrm{~g} \text { sucrose, } 1.5 \mathrm{ml} \text { aroma, } 075 \mathrm{~g} \text { citric acid, } 0 \mathrm{~g} \text { date } \\
\text { powders) }\end{array}$ & 75 & 15 & 10 & 1 \\
\hline & $\begin{array}{l}\text { A ( } 250 \mathrm{ml} \text { water, } 0 \mathrm{~g} \text { sucrose, } 1.5 \mathrm{ml} \text { aroma, } 075 \mathrm{~g} \text { citric acid, } 125 \mathrm{~g} \text { date } \\
\text { powders) }\end{array}$ & 70 & 20 & 10 & I \\
\hline & $\begin{array}{l}\text { B ( } 250 \mathrm{ml} \text { water, } 62.5 \mathrm{~g} \text { sucrose, } 1.5 \mathrm{ml} \text { aroma, } 075 \mathrm{~g} \text { citric acid, } 62.5 \mathrm{~g} \text { date } \\
\text { powders) }\end{array}$ & 65 & 15 & 20 & 1 \\
\hline & $\begin{array}{l}\mathrm{C}(250 \mathrm{ml} \text { water, } 62.5 \mathrm{~g} \text { sucrose, } 0 \mathrm{ml} \text { aroma, } 075 \mathrm{~g} \text { citric acid, } 62.5 \mathrm{~g} \text { date } \\
\text { powders) }\end{array}$ & 55 & 25 & 15 & 5 \\
\hline
\end{tabular}

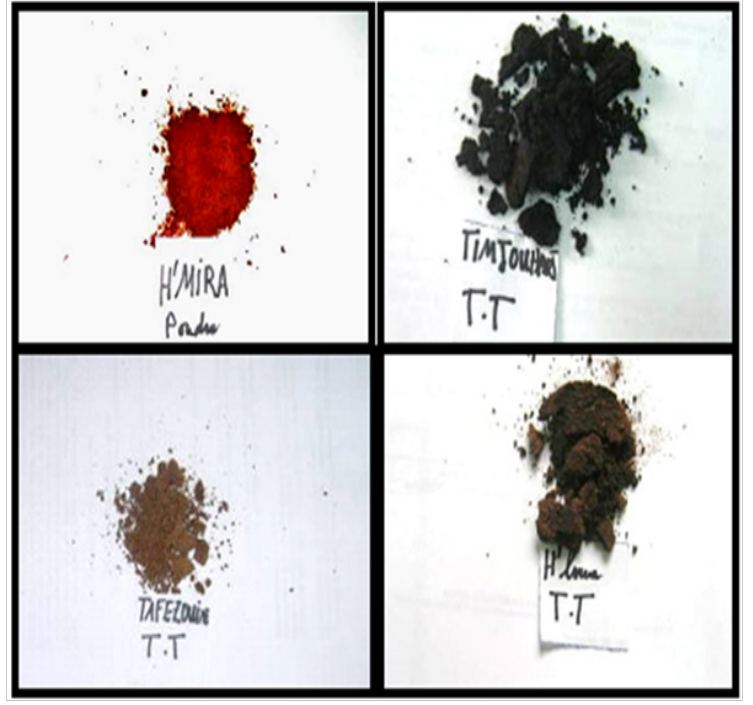

Figure 2 Powders of dates after heat treatment.

Citation: Hariri A, Ouis N, Bouhadi D. Effect of substitution of sugars by date powders variety H'lowa on the quality of the soft drinks. J Appl Biotechnol Bioeng. 20I7;3(6):450-457. DOI: 10.15406/jabb.2017.03.00083 


\section{Conclusion}

Date fruit (Phoenix dactylifera L.) is rich in carbohydrates and has a high nutritional value which makes it suitable for being used as an ingredient in confectioneries. The present work is a part of our scientific project about the valorisation of the common dates grown in Algeria. In recent years an important part of food research has been primarily focused on new formulation products. Date powders variety H'lowa show good quality and the highest color, taste and texture scores, it is used in many food preparations. For manufacture of Soft Drinks, total or partial replacement of sugars by $125 \mathrm{~g}$ of date powders (sample A) improves the nutritional quality of the product by increasing of reducing sugars, acidity and ash but decrease the level of the Total Solid Content. From the data presented in the current study, it could be concluded that the microbiological quality of most of the drinks prepared with date powders were not satisfactory as total plat count and, yeasts and moulds. Partial replacement of $62.5 \mathrm{~g}$ sugars by $62.5 \mathrm{~g}$ of the date powders (Samples B and C) improves the sensory quality of soft drinks included color, taste, acidity and odor.

\section{Acknowledgements}

We gratefully acknowledge Pr. I. Chevalot to have me to help to realize this work as well as all the team of the laboratory LRGP, ENSAIA, Nancy, France.

\section{Conflict of interest}

Authors declare if any financial interest or any conflict of interest exists.

\section{References}

1. Al Khalifah NS, Askari E, Shanavaskhan AE. Date palm tissue culture and genetical identification of cultivars grown in Saudi Arabia. National Center for Agriculture Technologies, Saudi Arabia: KACST; 2013.

2. Chandrasekaran M, Bahkali AH. Valorization of date palm (Phoenix dactylifera) fruit processing byproducts and wastes using bioprocess technology-Review. Saudi J Biol Sci. 2013;20(2):105-120.

3. Elhoumaizi MA, Saaidi M, Oihabi A, et al. Phenotypic diversity of datepalm cultivars (Phoenix dactylifera L.) from Morocco. Genet Resour Crop Evol. 2002;49(5):483-490.

4. Al Shahib W, Marshall RJ. The fruit of the date palm: its possible use as the best food for the future. Int J Food Sci Nut. 1993;54(4):247-259.

5. Al Hooti S, Sidhu JS, Al Otaibi J, et al. Date bars fortified with almonds, sesame seeds, oat flakes and skim milk powder. Plant foods for Human Nutrition. 1997;51(2):125-135.

6. Participative management on genetic resources of date palm in Maghreb oasis. USA: IPGRI International Plant Genetic Resources Institute; 2004.

7. Agricultural Statistics of Algerian Ministry of Agriculture. Algeria: SAA; 2011.

8. Ahmadnia A, Sahari MA. Using date powder in formula-tion of chocolate toffee. J Food Sc Technol. 2008;5(3):1-8.

9. Eyong EU, Eteng MU, Eyong UO. Comparative chemical analysis of some brand of soft drinks consumed in Southern Nigeria. Nig J Biochem Mol Biol. 2010;25:36-39.

10. Dharmasena KA. The Non-Alcoholic Beverage Market in the United States: Demand Interrelationships, Dynamics, Nutrition Issues and Probability Forecast Evaluation. USA: Texas A \& M University; 2010.
11. Phillip BB, Shittu AM, Ashaolu OF. Demand for non-alcoholic beverages among urban households in South West, Nigeria. Afr J Food Agric Nutr Dev. 2013;13(3):7853-7869.

12. Pofahl GM, Capps O, Clauson A. Demand for non alcoholic beverages: evidence from the AC-Nelson Home scan panel. Selected Paper presented at the American Agricultural economics Association annual meeting, Providence, Rhode Island, USA; 2005. p. 24-27.

13. Benahmed DA, Saidi N, Mekssoud A, et al. Pharmacological and biological proprieties of a mixture of date powders (mech-degla and spirulina). A multidisciplinary journal of global macro trends. 2013;2(1):310320 .

14. Benamara S, Khireddine $\mathrm{H}$, Amellal $\mathrm{H}$, et al. Drying and browning of date pulp during hot air and microwave drying. American Journal of Food Agriculture Nutrition and Development. 2009;9(5):1161-1173.

15. Official methods of Analysis of AOAC international. Gaithersburg. Maryland, USA: AOAC; 2007.

16. Garza S, Ibarz A, Pagan J, Giner J. Non-enzymatic browning in peach puree during heating. Food Res Int. 1999;32(5):335-343.

17. Dubois M, Gilles KA, Hamilton JK, et al. Colorimetric method for Determination of sugars and related substances. Analytical Chemistry. 1956;28(3):350-356.

18. Anon. Approved Methods of Analysis. 10th ed. St. Paul, USA: The American Association of Cereal Chemists (AACC); 2007.

19. Guiraud JP. Food Microbilogy. ED Ria, Dunod Paris, France; 2003.

20. Mossel DAA, Visser M, Mengerink WHJ. A comparison of media for the enumeration of moulds and yeasts in foods and beverages. Lab Pract. 1962;11:109-112.

21. Amellal H, Benamara S. Vacuum drying of common date pulp cubes. Drying Technol. 2008;26(3):378-382.

22. Metin M. Analysis Methods of Milk and Dairy products (Sensory, Physical and Chemical Analysis). Bornova, Turkey: Ege University Publications; 2006.

23. Ahmed J, Ramaswamy HS. Physico-chemical properties of commercial date pastes (Phoenix dactylifera L.). J Food Engr. 2006;76:348-352.

24. Belguedj M. Caractéristiques des cultivars de dattier du Nord-Est du Sahara algérien, éd. Biskra, Algeria: ITDAS; 1996.

25. Abekhti A, Zarour K, Boulal A, et al. Evaluation of microbiological quality of the date fruit product "Btana" produced in Adrar South Algeria. J Microbiol Res. 2013;3(5):163-170.

26. Barreveld WH. Date palm products. USA: FAO Agricultural Services Bulletin; 1993. $216 \mathrm{p}$.

27. Toutain G. Le palmier dattier, culture et production. Al Awamia. 1967;25:1-71.

28. Omowunmi SA, Ayoade LA. Nutritional composition of the fruit of the nigerian wild date palm, Phoenix dactylifera. World J Dairy \& Food Sci. 2013;8(2):196-200.

29. El Sharnouby GA, Aleid SM, Al Otaibi MM. Nutritional quality of biscuit supplemented with wheat bran and date palm fruits (Phoenix dactylifera L.). Food and Nutrition Sciences. 2012;3(3):322-328.

30. Salim-ur-Rehman N, Muhammad H, Javaid AA. Development and physico-chemical characterization of apricot-date bars. J Agric Res. 2012;50(3):409-421.

31. Amoros A, Pretel MT, Almansa MS, et al. Antioxidant and nutritional properties of date fruit from Elche grove as affected by maturation and phenotypic variability of date palm. Food Sc Technol Int. 2009;15(1):65-72. 
32. Mikki MS. Date palm post harvest processing technology in Saudi Arabia. Iran: Regional Workshop on Date Palm Post harvest Processing Technology; 1999.

33. Shahravy A, Tabandeh F, Bambai B, et al. Optimization of probiotic Lactobacillus casei ATCC 334 production using date powder as carbon source. CI \& CEQ. 2012;18(2):273-282.

34. Maatallah $\mathrm{S}$. Contribution à la valorisation des dattes. Thèse d'ingéniorat. INA- El-harrach, Algérie; 1970.

35. Borchani C, Besbes S, Blecker C, et al. Chemical properties of eleven date cultivars and their corresponding fiber extracts. Afr J Biotechnol. 2010;9(26):4096-4105.

36. Bourgeois CM, Leveau JY. Techniques d'analyse et de contrôle dans les industries agroalimentaires. 2nd ed. Paris, Lavoisier, Italy: Tec et Doc; 1991.476 p.

37. El-Sohaimy SA, Hafez EE. Biochemical and Nutritional Characterizations of Date Palm Fruits (Phoenix dactylifera L.). J Applied Sci Res. 2010;6:1060-1067.

38. Mikki MS, Al Taisan SM, Abdulaziz AA. Incorporation of date pulp for the manufacture of tomato ketchup. Date Palm Journal. 1987;5:215216.

39. Obiegbuna J, Akubor P, Ishiwu C, et al. Effect of substituting sugar with date palm pulp meal on the physicochemical, organoleptic and storage properties of bread. Afr J Food Sci. 2013;7(6):113-119.

40. Tufail F, Pasha I, Butt M, et al. Use of date syrup in the preparation of low caloric cakes replacing su-crose. Pakistan Journal of Agricultural Sciences. 2002;39:149-153.
41. Gad AS, Kholif AM, Sayed AF. Evaluation of the nutritional value of functional yogurt resulting from combination of date palm syrup and skim milk. American Journal of Food Technology. 2010;5(4):250-259.

42. Bassiouny MA, Yang J. Influence of drinking patterns of carbonated beverages on dental erosion. Gen Dent. 2005;53(3):207-210.

43. Ashurst PR. Chemistry and Technology of Soft drinks and Fruit Juices. 2nd ed. Vol. III (4) London, UK: Blackwell Scientific Publication; 2005. $433 \mathrm{p}$.

44. Amos Tautua W, Bamidele M, Diepreye ERE. Ultra-violet spectrophotometric determination of caffeine in soft and energy drinks available in yenagoa, Nigeria. Adv J Food Sci Technol. 2014;6(2):155-158.

45. Lin CI, Joseph AK, Chang CK, et al. Estimation of caffeine in tea samples by spectrophotometrically. Anal Chimica Acta. 2003;481:175180

46. Khan MM, Islam MT, Chowdhury MMH, et al. Assessment of microbiological quality of some drinks sold in the streets of Dhaka University Campus in Bangladesh. Int J Food Cont. 2015;2(4):1-5.

47. Prescott LM, Harly JP, Kleen DA. Food Microbiolgy. 5th ed. New York, USA: McGraw Hill; 2002. p. 352-627.

48. Ahmed MSU, Nasreen T, Feroza B, et al. Microbiological quality of local market vended freshly squeezed fruit juices in Dhaka City, Bangladesh. Bangladesh J Sci Ind Res. 2009;44(4):421-424.

49. Bryan FL, Michanie SC, Alvarez P, et al. Critical control points of street vended foods in the Dominican Republic. J Food Prot. 1998;51(5):373383. 